\title{
Screening IBR dan Diferensial Leukosit untuk Pengendalian Gangguan Reproduksi Sapi PO
}

\author{
(IBR Screening and Differential Leucocyte for Control of PO Cow \\ Reproductive Disorders)
}

\author{
Widyaningrum Y, Pamungkas D, Lukman A \\ Loka Penelitian Sapi Potong, Jl. Pahlawan No. 2, Grati, Pasuruan, Jawa Timur \\ drh.yeni@yahoo.com
}

\begin{abstract}
The purpose of this study was to determine the condition of reproductive disorders and how to control the Infectious Bovine Rhinotracheitis (IBR) by screening and differenciate leucocyte. 47 PO cows of 24 months old were examinated by anamnesis, clinical examination, control reproductive disorders with IBR screening tes and leucocyte differential inspection. Data obtained were analyzed by ANOVA and descriptive. Based on the results of the examination reported that $12(25.53 \%)$ of cows causes reproductive disorders include ovarian hypofunction and atrophy, 10 (21.27\%) pregnant cows and 25 (53.19\%) cattle were showing signs of estrus. The ADG PO cattle that causes reproductive disorders $0.31 \pm 0.09 \mathrm{~kg} / \mathrm{head} / \mathrm{day}$, where as in normal cow $0.54 \pm 0.15 \mathrm{~kg}$ head/day. Differential leucocyte count results showing the percentage of lymphocytes in both groups did not differ significantly each was $64.41 \pm 6.05$ and the $65.89 \pm 2.17$, while the percentage of neutrophil cells each was $26.75 \pm 1.93$ and $31.20 \pm 5.13$. Colorado IBR screening test results in both cattle groups, negative antibody negative. It was concluded that reproductive disorders in PO cows had no effect against IBR disease and the percentage of lymphocytes and neutrophils, but influenced by factors feed characterized by $\mathrm{PBBH}$ cows experiencing reproductive disorders were significantly different with normal cow.
\end{abstract}

Key Words: Reproductive Disorders, PO Cattle, IBR, Agricultural Technology Park

\begin{abstract}
ABSTRAK
Tujuan penelitian ini adalah untuk mengetahui kasus gangguan reproduksi pada sapi PO dan penanggulangannya dengan analisis screening Infectious Bovine Rhinotracheitis (IBR) serta diferensial leukosit. Sapi PO 47 ekor umur 24 bulan dilakukan anamnesa, pemeriksaan klinis, reproduksi dan pengendalian gangguan reproduksi dengan uji screening IBR dan pemeriksaan diferensial leukosit. Data dianalisis sidik ragam (ANOVA) dan deskriptif. Hasil pemeriksaan menunjukkan bahwa $12(25,53 \%)$ sapi PO mengalami gangguan reproduksi meliputi hipofungsi ovarium dan atropi, $10(21,27 \%)$ sapi sudah bunting dan $25(53,19 \%)$ sapi sudah menunjukkan estrus. PBBH sapi PO yang mengalami gangguan reproduksi lebih rendah 0,31 $\pm 0,09 \mathrm{~kg} / \mathrm{ekor} / \mathrm{hari}$ dibandingkan sapi normal $0,54 \pm 0,15 \mathrm{~kg} / \mathrm{ekor} / \mathrm{hari}$. Hasil penghitungan diferensial leukosit menunjukkan persentase limfosit pada kedua kelompok tidak berbeda signifikan masing-masing adalah $64,41 \pm 6,05$ dan $65,89 \pm 2,17$, sedangkan persentase sel neutrofil masing-masing adalah $26,75 \pm 1,93$ dan 31,20 $\pm 5,13$. Hasil pengujian screening IBR Colorado pada kedua kelompok ternak antibodi negatif. Disimpulkan bahwa gangguan reproduksi pada sapi PO tidak berpengaruh terhadap penyakit IBR serta persentase sel limfosit dan neutrofil, namun dipengaruhi oleh faktor pakan ditandai dengan PBBH sapi yang mengalami gangguan reproduksi berbeda nyata dengan sapi normal.
\end{abstract}

Kata Kunci: Gangguan Reproduksi, Sapi PO, IBR, Taman Teknologi Pertanian 


\section{PENDAHULUAN}

Peningkatan populasi sapi potong dan efisiensi reproduksi perlu dilakukan dengan melakukan upaya penanganan gangguan reproduksi. Lambatnya laju pertambahan populasi ternak di lapangan disebabkan oleh adanya penurunan performa ternak akibat dari gangguan reproduksi. Oleh sebab itu sampai saat ini gangguan reproduksi merupakan salah satu masalah penting yang mempengaruhi produksi dan produktivitas sapi potong. Gangguan reproduksi secara langsung akan berakibat pada infertilisas dan sterilitas sehingga terjadi repeat breeding dan kegagalan kebuntingan. Secara tidak langsung gangguan reproduksi mengakibatkan estrus post partum lebih dari 90 hari, days open (DO) lebih panjang 85 hari, calving interval lebih dari 12-15 bulan, service per conception (S/C) lebih dari 1,5 dan conception rate kurang dari 60\% serta rendahnya angka kelahiran pedet (Gitonga 2010). Kondisi tersebut menimbulkan kerugian peternak yaitu meningkatnya biaya pakan dan pemeliharaan, biaya perkawinan (IB dan kawin alam), pengobatan, penurunan produktivitas dan populasinya.

Beberapa faktor penyebab gangguan reproduksi pada sapi potong yaitu agen non infeksius (kegagalan hormonal, defisiensi nutrisi, keturunan, manajemen pemeliharaan) dan infeksius (penyakit). Aspek nutrisi seperti kekurangan pakan, ketidakseimbangan protein, vitamin, energi dan mineral merupakan faktor yang berpengaruh pada reproduksi ternak (Pryce et al. 2001). Asupan nutrien ransum yang belum mencukupi kebutuhan menyebabkan performa reproduksi sapi potong betina menjadi tidak efisien. Nutrisi dibutuhkan oleh ternak dalam metabolisme, merangsang hipotalamus dan mempengaruhi status hormonal, laktasi, pertumbuhan dan aktivitas reproduksi. Kebutuhan nutrisi yang tidak mencukupi kebutuhan ternak/malnutrisi akan mengakibatkan tertundanya pubertas dan hipofungsi ovarium. Sedangkan gangguan reproduksi oleh agen infeksius atau penyakit menular dapat menyebabkan abortus, endometritis, infertil, dan kematian embrio. Salah satu jenis penyakit reproduksi menular pada sapi potong yaitu infectious bovine rhinotracheitis (IBR). Penyakit ini disebabkan oleh virus dengan gejala klinis pustular vulvovaginitis yang dapat menyebabkan infertile temporer (Adjid 2014).

Kondisi di lapangan pada usaha peternakan rakyat banyak dijumpai produktivitas sapi masih rendah disebabkan oleh gangguan reproduksi hipofungsi ovari, korpus luteum persisten, sistik ovari, endometritis, distokia dan abortus (Achjadi 2013). Pengendalian kasus atau penyakit reproduksi perlu diketahui dengan baik oleh peternak, sehingga kerugian akibat penyakit dapat ditekan dan keuntungan dapat dioptimalkan. Oleh sebab itu perlu dilakukan upaya pengendalian gangguan reproduksi yang salah satunya dengan melakukan pengujian penyakit IBR dengan screening tes dan diferensial leukosit sebagai konfirmasi. Tujuan penelitian ini adalah untuk mengetahui kasus gangguan reproduksi pada sapi Peranakan Ongole (PO) betina dan penanggulangannya dengan analisis screening tes IBR, diferensial leukosit, dan vit ADE.

\section{MATERI DAN METODE}

\section{Waktu dan tempat penelitian}

Penelitian ini dilaksanakan pada bulan Juli sampai Oktober tahun 2016 di Taman Teknologi Pertanian (TTP), Desa Banyubang, Kecamatan Selokuro, Kabupaten Lamongan dan Laboratorium Reproduksi Loka Penelitian Sapi Potong Grati, Jawa Timur, serta analisis penyakit IBR di Balai Besar Penelitian Veteriner Bogor. 


\section{Sampel penelitian}

Sampel yang digunakan dalam penelitian ini adalah Sapi PO betina berjumlah 47 ekor umur 24-36 bulan, yang dipelihara di kandang kelompok. Kemudian dilakukan pengambilan sampel darah sapi dari vena jugularis menggunakan venoject dan tabung darah tanpa anti koagulan, kemudian sampel darah di-centrifuge dengan kecepatan $4.000 \mathrm{rpm}$ selama 15 menit. Selanjutnya serum darah dianalisis screening IBR dan pemeriksaan ulas darah.

\section{Metode pemeriksaan}

Pemeriksaan kondisi reproduksi dan gangguan reproduksi sapi PO betina dengan metode anamnesa, pemeriksaan klinis dan palpasi rektal. Pemeriksaan klinis dengan melihat pertumbuhan bobot badan harian $(\mathrm{PBBH})$ dan palpasi rektal pada organ reproduksi. Sedangkan penanganan gangguan reproduksi dengan screening IBR Colorado menggunakan uji SN, pemeriksaan diferensial leukosit, dan pemberian Vit ADE.

\section{Prosedur diferensial leukosit}

Pemeriksaan ini dilakukan untuk mengetahui perbedaan bentuk-bentuk sel darah putih yaitu neutrofil dan limfosit. Sampel darah diteteskan pada gelas objek, kemudian gelas objek lainnya ditempatkan pada bagian darah tadi dengan membentuk sudut $30^{\circ}$ dan didorong sepanjang gelas objek sampai terbentuk usapan darah tipis. Ulasan darah dikeringkan di udara, kemudian difiksasi dengan metanol selama 5 menit, lalu dimasukkan ke dalam pewarna giemsa 10\% selama 30 menit. Selanjutnya dicuci dengan air mengalir dan dikeringkan di udara. Preparat ulas darah diperiksa di bawah mikroskop dengan pembesaran 1000 kali untuk pengamatan persentase jumlah diferensial leukosit darah. Pengamatan dilakukan berdasarkan 15 kali lapang pandang.

\section{Parameter yang diukur}

Parameter yang diukur adalah status PBBH, reproduksi sapi PO, penyakit IBR dan jumlah sel darah putih (limfosit dan neutrofil).

\section{Analisis data}

Data yang diperoleh dianalisis dengan sidik ragam ANOVA dan secara deskriptif.

\section{HASIL DAN PEMBAHASAN}

Hasil pengamatan pemeriksaan palpasi rektal tertuang pada Gambar 1. Dari 47 ekor sapi PO betina yang mengalami gangguan reproduksi sebesar 12 ekor $(25,53 \%)$ meliputi hipofungsi ovarium dan atropi. Sedangkan 10 ekor $(21,27 \%)$ sapi sudah bunting dan 25 ekor $(53,19 \%)$ sapi sudah menunjukkan gejala estrus. Sapi PO yang mengalami kasus gangguan reproduksi sebesar 25,53\% meliputi hipofungsi ovarium sebanyak 9 ekor (75\%) dan atropi sebanyak 3 ekor (25\%). Sedangkan sebanyak 25\% sapi yang hipofungsi ovarium telah normal reproduksinya. Hipofungsi ovarium merupakan kondisi patologi akibat defisiensi nutrisi sehingga ovarium tidak dapat berkembang dan berfungsi dengan normal. Pada kasus seperti ini ternak sapi dalam waktu yang lama akan berlanjut menjadi atropi yang bersifat irreversibel apabila tidak dilakukan perbaikan pakan dan lingkungan. 
Menurut Khamas (2011) sapi potong yang terdiagnosa hipofungsi ovarium menunjukkan gejala klinis tidak adanya tanda birahi (anestrus) akibat dari tidak berkembangnya folikel di ovarium dan lamanya waktu anestrus post partus $>90$ hari.

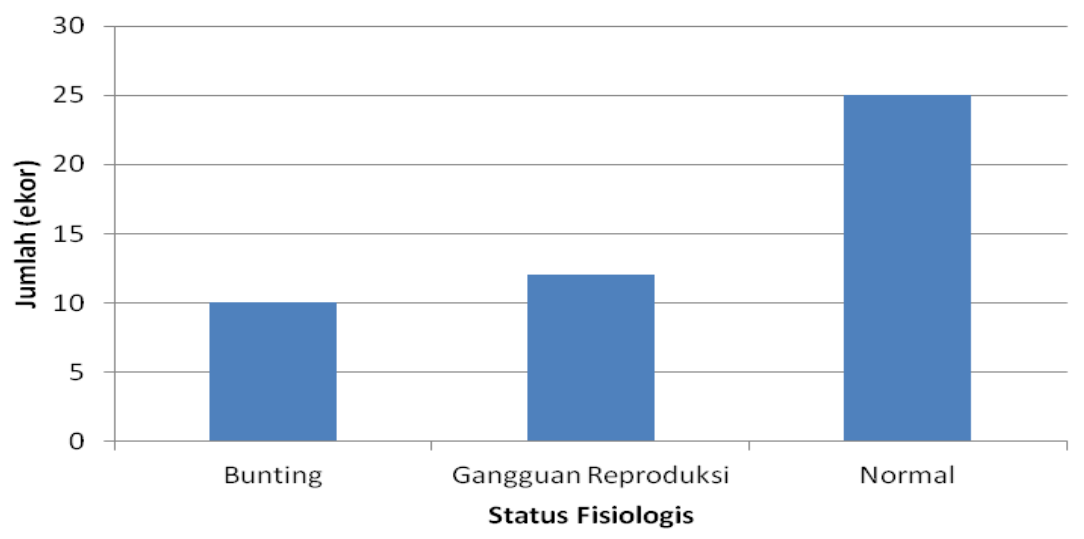

Gambar 1. Status fisiologis sapi PO di TTP Lamongan

Kawasan taman teknologi pertanian, desa Banyubang merupakan areal pertanaman jagung seluas 195 ha sehingga ketersediaan limbah pertanian tanaman jagung pada musim hujan cukup melimpah. Namun pada musim kemarau ketersediaan pakan hijauan sedikit dan ternak kekurangan konsentrat sehingga keseimbangan nutrisi masih rendah. Terutama terjadi antara bulan Juni sampai September di mana hampir tidak ada hujan sama sekali (sangat kering). Menurut Murphy et al. (1991) jumlah dan kualitas pakan yang tidak cukup akan mempengaruhi pertumbuhan folikel dan fungsi luteal pada siklus estrus. Kurangnya asupan nutrisi mempengaruhi peningkatan hormon insulin-like growth faktor-I (IGF-I) dalam merangsang hipofisis anterior dan hipotalamus terhadap fungsi ovarium dan sensitivitas gonadotropin releasing hormon $(\mathrm{GnRH})$. Energi tubuh akan menekan GnRH dan luteinizing hormon sehingga kegagalan tumbuhnya folikel pada ovarium dalam menghasilkan hormon estradiol (Budiyantono et al. 2016). Kondisi ini akan menghambat pubertas, folikel tidak dapat berkembang menjadi atresia dan hipofungsi ovarium apabila tidak segera dilakukan penanganan akan berlanjut menjadi atropi.

Idealnya sapi PO pertama kali kawin pada umur 26 bulan dan beranak pertama 36 bulan (Astuti 2004). Namun sapi PO di TTP Kabupaten Lamongan pada umur lebih dari 24 bulan sebanyak 12 ekor belum menunjukkan gejala birahi atau belum memasuki masa siap untuk dikawini pejantan. Berdasarkan kondisi badan sapi yang mengalami hipofungsi ovarium/atropi mempunyai pertambahan bobot badan harian $(\mathrm{PBBH})$ yang rendah. Ratarata $\mathrm{PBBH}$ sapi $\mathrm{PO}$ yang mengalami gangguan reproduksi 0,31 $\pm 0,09 \mathrm{~kg} / \mathrm{ekor} / \mathrm{hari}$, sedangkan pada sapi yang menunjukkan gejala estrus PBBH 0,54 $\pm 0,15 \mathrm{~kg} / \mathrm{ekor} / \mathrm{hari}$. $\mathrm{PBBH}$ kelompok sapi yang mengalami gangguan reproduksi berbeda nyata $(\mathrm{P}<0,05)$ dengan sapi yang normal. Kondisi tubuh yang rendah akan mempengaruhi kinerja reproduksi ternak (Pradhan 2008).

Berdasarkan hasil pemeriksaan sel darah putih yang disajikan pada Gambar 3, kelompok ternak yang mengalami gangguan reproduksi (hipofungsi ovarium dan atropi) jumlah sel limfosit dan neutrofil tidak berbeda nyata $(\mathrm{P}>0,05)$ dengan kelompok sapi normal. Pada kelompok ternak yang mengalami hipofungsi ovarium dan atropi persentase sel limfosit sebesar $(64,41 \pm 6,05)$ dan neutrofil sebesar $(26,75 \pm 1,93)$. Sedangkan persentase sel limfosit pada sapi yang menunjukkan estrus dan sudah bunting $(65,89 \pm 2,17)$ dan neutrofil sebesar $(31,20 \pm 5,13)$. Jumlah limfosit dan neutrofil tidak berpengaruh secara langsung terhadap gangguan reproduksi karena persentase sel limfosit dan neutrofil masih dalam batas normal. Hal ini sesuai dengan hasil penelitian Putri (2014) jumlah sel neutrofil dan limfosit 
pada sapi dengan kasus S/C 1,0-2,0 tidak berbeda nyata dengan sapi S/C >2,0. Namun pada sapi dengan kasus nilai Estrus Post Partus (epp) 30-60 hari jumlah sel limfosit berbeda nyata $(\mathrm{P}<0,05)$ dibandingkan dengan kelompok sapi dengan nilai epp $>60$ hari.

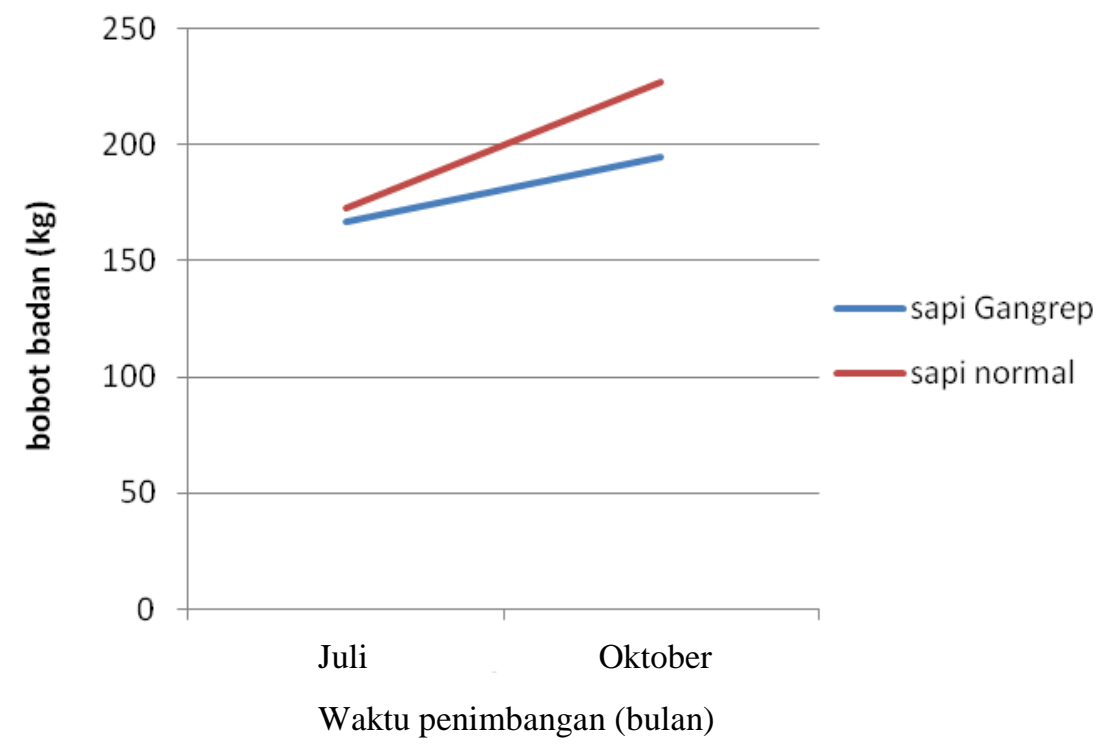

Gambar 2. Pola pertumbuhan sapi PO di TTP Lamongan

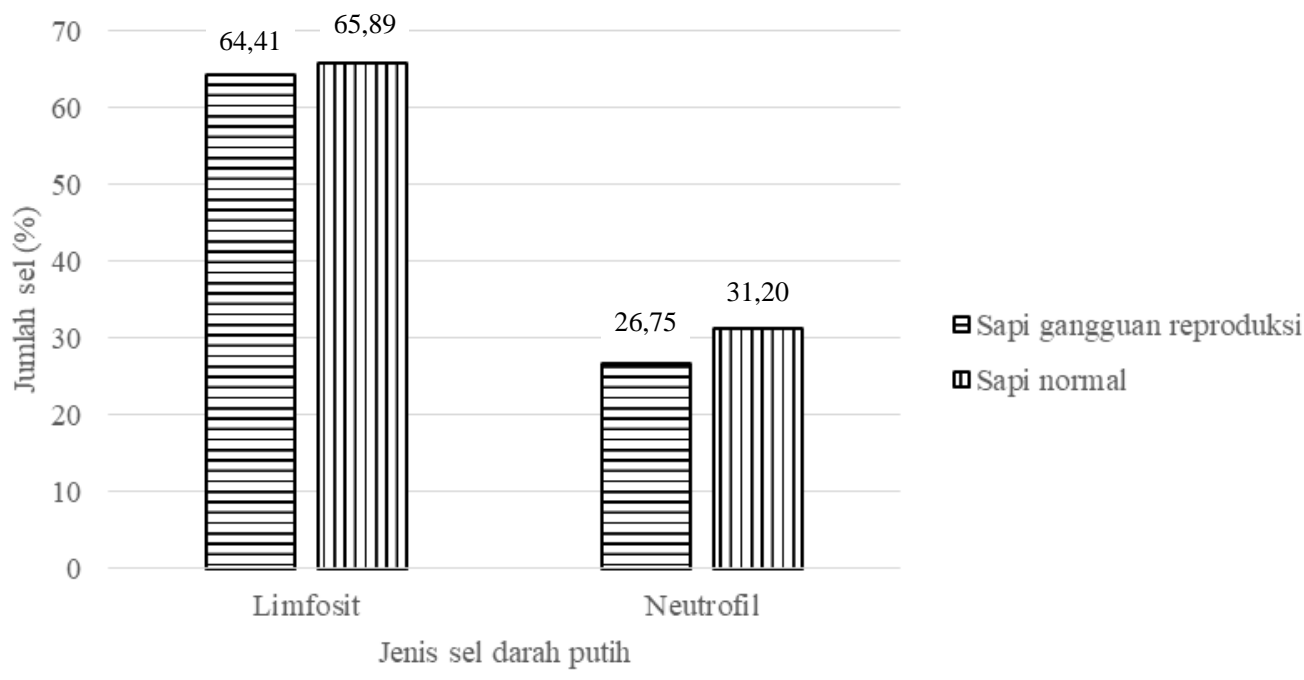

Gambar 3. Kadar sel darah putih sapi PO di TTP Lamongan

Pengendalian gangguan reproduksi akibat agen infeksius dilakukan dengan melakukan pengujian screening dan titrasi antibodi virus IBR Colorado, dengan uji SN pada 47 ekor sapi diperoleh hasil antibodi negatif artinya tidak memiliki antibodi/kekebalan. IBR merupakan salah satu penyakit reproduksi menular berdampak pada kinerja reproduksi, menimbulkan kerugian ekonomi yang cukup besar dan berakibat pada rendahnya efisiensi reproduksi sapi potong. Disebabkan oleh Bovine herpesvirus 1 (BoHV-1). Sapi yang terinfeksi penyakit ini akan infertil, endometritis, dan abortus fetus 3 minggu sampai 3 bulan (Adjid 2014). Oleh karena itu, sapi yang mengalami gangguan reproduksi hipofungsi ovarium dan atropi tidak berpengaruh terhadap seropositip IBR.

Penanggulangan kasus gangguan reproduksi juga dilakukan dengan melakukan penempatan terpisah dari kandang komunal, dan memberikan perlakuan pakan khusus 
dengan memperbaiki kualitas dan kuantitas pakan untuk membantu nutrisi ternak. Harapannya sapi bisa mencapai skor kondisi tubuh (SKT) di atas 6 (skor 1-9). Evaluasi nutrisi dan imbangan energi tubuh secara klinis melalui PBBH. Menurut Budiyantono (2016) fenomena reproduksi pada sapi potong akibat dari faktor nutrisi yang lebih kritis dibandingkan faktor yang lainnya. Nutrisi yang cukup mendorong proses biologis untuk mencapai potensi genetik ternak dan meminimalisasi performa ternak dari pengaruh lingkungan/manajemen yang kurang mendukung. Selain itu dilakukan juga penyuntikan Vitamin ADE pada sapi-sapi yang mengalami kasus gangguan reproduksi. Vitamin ini berperan penting dalam fertilitas dan terlibat pada produksi hormon serta pemeliharaan imunitas tubuh yang kuat. Vitamin ADE akan merangsang perkembangan folikel untuk mencapai folikel dominan. Selain itu, mineral makro seperti kalsium (Ca), magnesium $(\mathrm{Mg})$ dan fosfor $(\mathrm{P})$, serta mineral mikro seperti tembaga $(\mathrm{Cu})$, selenium $(\mathrm{Se})$ dan seng (Zn) juga berperan penting (Sarker et al. 2015).

\section{KESIMPULAN}

Gangguan reproduksi pada sapi PO di kawasan Taman Teknologi Pertanian yang meliputi hipofungsi ovarium dan atropi tidak berpengaruh terhadap infectious bovine rhinotracheatis (IBR) dan persentase sel limfosit dan neutrofil namun dipengaruhi oleh faktor pakan ditandai dengan $\mathrm{PBBH}$ sapi yang mengalami gangguan reproduksi lebih

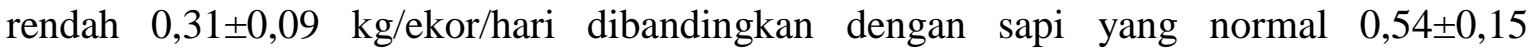
$\mathrm{kg} / \mathrm{ekor} / \mathrm{hari}$.

\section{UCAPAN TERIMA KASIH}

Terima kasih kepada kepala Balai Pengkajian Teknologi Pertanian Jawa Timur, Ketua dan anggota kelompok ternak taman teknologi pertanian Desa Selopuro, Kecamatan Banyubang, Kabupaten Lamongan, Kepala Loka Penelitian Sapi Potong serta Dyah Tuwi Ramsiati sudah membantu kegiatan penelitian ini.

\section{DAFTAR PUSTAKA}

Achjadi K. 2013. Manajemen kesehatan reproduksi dan biosekuriti. Makalah Pertemuan Swasembada Persusuan di Indonesia. Yogyakarta (Indonesia).

Astuti M. 2004. Potensi dan keragaman sumberdaya genetik sapi Peranakan Ongole (PO). Wartazoa. 4:98-106.

Adjid ARM. 2014. Strategi alternatif pengendalian penyakit reproduksi menular untuk meningkatkan efisiensi reproduksi sapi potong. Wartazoa. 14:125-132.

Budiyantono A, Tarsius CT, Triguntoro, Heni KD. 2016. Gangguan reproduksi sapi Bali pada pola pemeliharaan semi intensif di daerah sistem integrasi sapi - kelapa sawit. Acta Vet Indones. 4:14-18.

Gitonga PN. 2010. Pospartum reproductive performance of dairy cows in medium and large scale farms in Kiambu and Nakuku District of Kenya [Thesis]. Nairobi (Kenya): University of Nairobi Faculty of Veterinary Medicine.

Khamas DJ. 2011. Hormonal treatments of inactive ovaries of cows and buffaloes. J Vet Sci. 44:7-13.

Murphy MG, Enright WJ, Crowe MA, Mc Conneel K, Spicer LJ, Boland MP, Roche JF. 1991. Effect of dietary intake on pattern of growth of dominant follicle during the estrus cycle in beef heifers. J Reprod Fertil. 92:333-338. 
Putri AN. 2014. Jumlah limfosit dan neutrofil dihubungkan dengan service per conseption (s/c), calving interval (ci) dan estrus post partum (epp) pada sapi potong di Yogyakarta [Thesis]. Yogyakarta (Indonesia): Universitas Gadjah Mada.

Pradhan R.2008. Reproductive disorders in cattle due tonutritional status. J Int Dev Coop. 14:45-46.

Pryce JE, Coffey MP, Simmg. 2001. The relationship between body condition score and reproductive performance. J Dairy Sci. 84:1508-1515.

Sarker PK, Rahman MM, Shamsudin. 2015. Effects of GnRH analogue and vitamin ADE on induction of cyclicity in anoestrus heifers. Bangladesh J Vet Med. 13:33-40.

\section{DISKUSI}

\section{Pertanyaan}

1. Apa yang menjadi pertimbangan untuk dilakukannya skrining IBR, apakah berdasarkan gejala klinis yang muncul atau gangguan reproduksi. Apa ada hubungan kasus reproduksi dengan IBR, menurut saya kasus reproduksi banyak dipengaruhi oleh pakan

2. Apa peningkatan insulin growth promotor diukur?

\section{Jawaban}

1. gangguan reproduksi dapat terjadi oleh agen infeksius dan non infeksius. Untuk non infeksius dapat disebabkan oleh pakan, sedangkan untuk yang infeksius contohnya penyakit IBR yang dapat menyebabkan abortus. Infertilitas kami uji dengan melihat faktor infeksius dan non infeksius.

2. Kami tidak melihat insulin growth promotor tapi hanya nutrisinya. 